\title{
California oak-woodland overstory species affect herbage understory: Management implications
}

\author{
RAYMOND D. RATLIFF, DON A. DUNCAN, AND STANLEY E. WESTFALL
}

\section{Abstract}

Concerns for the future of California's oak-woodlands have intensified the need to better understand how different overstory species affect herbage standing crops and species frequencies. Data from over 8,000 plots harvested between 1961 and 1968 at the San Joaquin Experimental Range in the Sierra Nevada foothills of central California show that peak standing crops averaged 2,795 $\mathrm{kg} / \mathrm{ha}$ in the open; $3,086 \mathrm{~kg} / \mathrm{ha}$ under blue oak (Quercus douglasii); 1,840 kg/ha under interior live oak (Quercus wislizenii); 1,696 $\mathrm{kg} / \mathrm{ha}$ under digger pine (Pinus sabiniana); and $1,917 \mathrm{~kg} / \mathrm{ha}$ under buck brush (Ceanothus cuneatus). Overstory species affected standing crops differently on different range sites. On swales, standing crops were less under live oak and digger pine than in open areas. On open-rolling uplands, standing crops were less in the open and under live oak than under blue oak. On rocky-brush uplands, standing crops were less under all other overstory species than under blue oak. Data on species frequency suggest that herbage species of later successional stages are more common under trees. The frequency of plant species varied with the species of overstory, and a diversity of overstory species may help to maintain adequate species diversity among understory species.

Key Words: annual grassland, blue oak, digger pine, herbage standing crops, live oak, species frequencies

Livestock grazing, fuelwood harvesting, land clearing, and foothill urbanizing all affect California's oak-woodlands. Maintaining viable overstory populations is a prime concern of landowners, environmentalists, and State agencies. Altering the overstory structure would likely alter the understory structure, which in turn may alter wildlife and fish habitats. How different overstory species can affect understory plant communities needs to be understood.

Blue oak (Quercus douglasii) is the dominant tree species on most of the oak-woodland surrounding California's Central Valley. Rangelands dominated by blue oaks are estimated to cover $1,178,000$ ha (Bolsinger 1987). Much of the blue oak area is used to produce livestock (mainly beef). Livestock grazing herbage produced under and around blue oaks, and they browse the oaks and eat acorns as well.

Blue oaks affect understory forage production and species composition. Generally, in the southern part of its range, blue oak provides adequate green feed earlier and in greater amounts than in the open areas (Duncan 1967; Duncan and Clawson 1980; Holland 1976,1980 ). The effect may be especially striking during periods of drought (Duncan and Reppert 1960, Holland 1980, Frost and McDougald 1989). In the northern part of its range, herbage standing crops are lower under blue oaks than in the open (Bartolome 1986, 1987; Kay 1987; Kay and Leonard 1980). Differences in oak density and canopy cover help explain the disparity in response: southern stands are frequently less dense and have less

Authors are range scientist, Pacific Southwest Forest and Range Experiment Station (PSW), USDA Forest Service, 2081 E. Sierra, Fresno, Calif. 93710 ; research consultant, San Joaquin Experimental Range, California State University, Fresno Calif. 93740; range technician (retired), PSW, USDA Forest Service, 2081 E. Sierra, Fresno, Calif. 93710.

We thank all persons from the Pacific Southwest Forest and Range Experiment Station who were involved in collecting the data, but especially, J. Anderson and C Burns (laboratory technicians); C. Conrad, C. Graham, M. Reed, and J. Reppert (range scientists); and E. Woolfolk (division chief/assistant director).

Manuscript accepted 14 September 1990. overstory canopy cover than northern stands.

In southern stands, ripgut brome (Bromus diandrus) and wild oats (Avena fatua) generally comprise more of the herbage (by weight) under blue oaks than in open grassland (Holland 1980). However, soft chess (B. mollis), foxtail fescue (Vulpia megalura), and broad-leaf filaree (Erodium botrys) generally comprise more of the herbage in open grassland than under blue oaks. In northern stands total grass cover is greater in open areas than under blue oaks, and ripgut brome as well as soft chess cover increase where trees are removed (Kay 1987). In contrast, little is known about the relationships of other oak-woodland overstory species to understory herbage.

In 1961 a study of 3 grazing regimes was started at the USDA Forest Service's San Joaquin Experimental Range, north of Fresno in Madera County, California. Major associates of blue oak at the Experimental Range are interior live oak ( $Q$. wislizenii), digger pine (Pinus sabiniana), and buck brush (Ceanothus cuneatus). Buckeye (Aesculus californica), Mariposa manzanita (Arctostaphylos mariposa), chaparral coffeeberry (Rhamnus californica cuspidata), and hollyleaf coffeeberry ( $R$. crocea ilicifolia) are common (Larson et al. 1985).

This paper reports a by-product of data from more than $\mathbf{8 , 0 0 0}$ plots sampled during the study at the Experimental Range that helps our understanding of how different overstory species affect herbage species and peak standing crops. The findings provide land managers greater information upon which to base overstory manipulations.

\section{Methods}

\section{Setting}

The San Joaquin Experimental Range occupies about 1,862 ha of oak-woodland in the Sierra Nevada foothills. Elevations range from 213 to $518 \mathrm{~m}$. Winters are relatively cool and wet; summers are hot and dry. Annual precipitation averages $48.3 \mathrm{~cm}$. The wettest months are December $(8.6 \mathrm{~cm})$, January $(8.3 \mathrm{~cm})$, and February $(8.6 \mathrm{~cm})$. July and August are the driest months with $2.5 \mathrm{~mm}$ each. January is the coldest month with average temperatures of $11.8^{\circ} \mathrm{C}$ (maximum) and $0.7^{\circ} \mathrm{C}$ (minimum). July is the hottest month with average temperatures of $36.7^{\circ} \mathrm{C}$ (maximum) and $16.2^{\circ}$ C (minimum).

Weather produces 3 characteristic forage seasons (Bentley and Talbot 1951). The "inadequate green"season begins after fall rains stimulate seed germination. During that forage season, environmental conditions usually limit plant growth. The "adequate green" season begins in January or February when major grass species are 5 to $8 \mathrm{~cm}$ tall. During that forage season, growth so accelerates that livestock cannot use all the herbage produced. The "dry" season begins when soil water becomes depleted in May or June. As the adequate green season ends and the dry season begins, the annual plants produce seed and die.

Soil type and depth, slope, and exposure along with weather are the major determinants of herbage production. Major range sites at the Experimental Range comprise $6 \%$ swales, $11 \%$ open-rolling uplands, and $83 \%$ rocky-brushy uplands of the area (Bentley and Talbot 1951, Caldwell et al. 1985, Gaylord 1972). Soil textures are coarse study loams, with soil depth and herbage production 
decreasing and granitic rock volume and slope increasing from the swales to the brushy uplands.

\section{Data Source}

The study (1961-1968) at the Experimental Range was designed to compare livestock and herbage responses to repeated seasonal, rotated seasonal, and continuous grazing on unfertilized pastures and continuous grazing on pastures fertilized with elemental sulfur. Livestock responses to the grazing regimes showed continuous grazing to be best for cow-calf production (Ratliff 1986). Fertilization did not increase the standing crop on swale sites, but increased it on open-rolling and rocky-brushy upland sites; and fertilization increased soft chess and ripgut brome on all sites (Caldwell et al. 1985). While repeated seasonal grazing altered the contribution of individual species, peak standing crops were not affected by grazing system (Richard M. Caldwell, John W. Menke, and Don A. Duncan, unpublished manuscript provided the authors by John W. Menke).

In the study, plots $0.1 \mathrm{~m}^{2}(30.5 \times 30.5 \mathrm{~cm})$ were systematically laid out along 6 randomly located permanent transects across each of 8 pastures but allocated to have 25 in swales, 18 in open-rolling uplands, and 70 in rocky-brushy uplands. The plot locations were protected with a San Joaquin cage (Westfall and Duncan 1961) and moved a random distance each year to avoid repeated sampling of the same areas.

The overstory, including "open" (no overstory), at each plot was recorded during sampling. Sample sizes for each overstory therefore depended on the number of plots occurring under the canopies. Overstory species identified separately were: blue oak, interior live oak, digger pine, and buck brush-including chaparral whitethorn (C. leucodermis). All other overstory species were grouped.

Plots were sampled for herbage biomass and species frequency when standing crops peaked. Herbage in each plot was harvested, oven dried and weighed. Frequency was determined as the proportion of quadrats where a species was the first hit by or nearest to one or more points. A quadrat consisted of a frame of 5 points.

Species composition based on that data was not computed because estimates of point frequency using "nearest-plant hits" are biased. The probability of selection depends on species abundance and spatial distribution and a variable plot size.

Grass species and groups identified were soft chess, ripgut brome, slender wild oats (A. barbata), Australian chess (B. arenarius), red brome (B. rubens), Mediterranean barley (Hordeum hystrix), , annual fescue (Vulpia spp.), and other grasses. Other plant species and groups identified were grasslikes (Carex spp. and Juncus spp.), broad-leaf filaree, other broad-leaves, Spanish clover (Lotus purshianus), clover (Trifolium spp.), and other legumes.

\section{Analyses}

The 1961-1968 study was not specifically designed to address overstory/understory relationships. Analysis of those relationships using the factorial design of the study was judged, therefore, to be inappropriate. The data from the study were pertinent, nevertheless, and a source of information impossible or prohibitively expensive to duplicate.

Each data case was considered to be an independent observation; and, because of known effects, data from the fertilized pastures were analyzed separately. Standing crop data were grouped, by range site and overstory species over all pastures over all years. Frequency data were grouped by overstory species over all range sites, pastures, and years.

For each range site, the null hypothesis that there are no differences in mean standing crops among the various overstory species was tested by one-way analysis of variance. The $95 \%$ confidence intervals for pair-wise differences among overstory species means

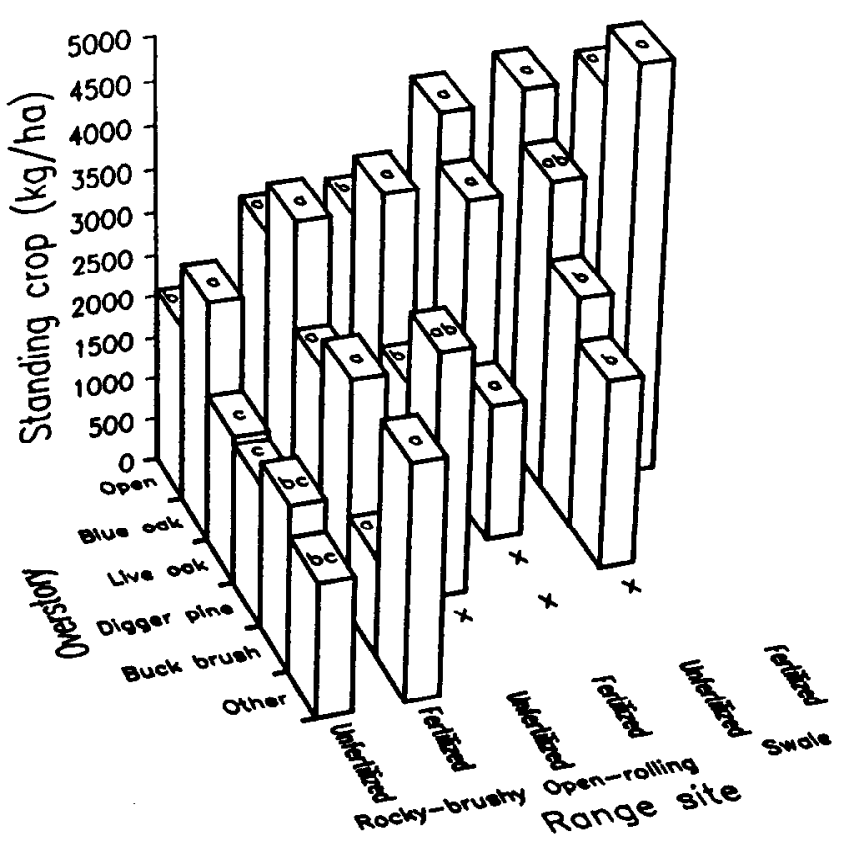

Fig. 1. Average peak herbage standing crops by overstory species on upland and swale range sites at the San Joaquin Experimental Range, 1961-1968. Within fertilizer treatments, within range sites, columns with the same letter do not differ significantly $(P<0.05)$ by Tukey's wprocedure. An $X=1$ plot, therefore, the variance could not be estimated.

were determined by Tukey's "w-procedure" modified to correct for the numbers of observations in the 2 means being compared (Steel and Torrie 1960). Differences between overstory species in standing crops were expressed as $(X 1-X 2) \pm w$.

We estimated the frequencies $\left(p=n_{i j} / n_{j}\right)$ of each herbaceous species by overstory species, in which, $\mathrm{n}_{\mathrm{ij}}$ is the number of quadrats where species (i) occurred under overstory ( $j$ ), and $n_{j}$ is the number of quadrats under overstory $(j)$. In those cases where $n_{i j}=1$, p was not estimated. We tested the hypothesis of no difference in frequencies of a herbaceous species under 2 overstory species $\left(p_{1}=p_{2}\right)$ using the $95 \%$ confidence interval (CI) for the difference, $\mathrm{p}_{1}-\mathrm{p}_{2}$. We followed the procedure of Dixon and Massey (1957) in computing the $C I$ when $p\left(n_{i j}\right)$ and $q\left(n_{i j}\right)$ were above 5 for both overstory species. When the $C I$ did not include zero, we rejected the hypothesis.

\section{Results and Discussion}

\section{Herbage Standing Crops}

On unfertilized swales, the average standing crop in the open areas was greater than under live oaks or digger pines but no greater than under blue oaks (Table 1, Fig. 1). Interpretation of the 95\% confidence interval for the difference between the open and blue oak overstory, nevertheless, suggests that actual standing crops in open areas were greater. We are $95 \%$ confident that any true difference favoring the open was at most $1,660 \mathrm{~kg} / \mathrm{ha}(631+$ $1,029 \mathrm{~kg} / \mathrm{ha}$ ), and that any true differences favoring the blue oak overstory was at most $398 \mathrm{~kg} / \mathrm{ha}(631-1,029 \mathrm{~kg} / \mathrm{ha})$. At those extremes, a difference in favor of the open would be biologically important, but for blue oaks would not be.

Overstory effects were somewhat more apparent on unfertilized open-rolling and rocky-brushy uplands. On those range sites, average standing crops were greater under blue oaks than in the open or under live oaks. In addition, the average standing crop on rocky-brushy upland was greater under blue oaks than under digger pine, buck brush or other; and the average standing crop in open areas was greater than under live oaks and digger pines. 
Table 1. Average peak herbage standing crops and their differences (expressed as $95 \%$ confidence intervals) by overstory species for unfertilized swales, and open-rolling, and rocky-brushy uplands at the San Joaquin Experimental Range, Madera County, California, $1961-1968$.

\begin{tabular}{|c|c|c|c|c|c|c|}
\hline \multirow{2}{*}{$\begin{array}{l}\text { Overstory species } \\
\text { (sample size) }\end{array}$} & \multirow{2}{*}{$\begin{array}{c}\text { Average } \\
\text { production }\end{array}$} & \multicolumn{5}{|c|}{ Differences in standing crops (e.g., open-blue oak) } \\
\hline & & Blue oak & Live oak & Digger pine & Buck brush & Other \\
\hline \multirow{7}{*}{$\begin{array}{l}\text { All types (1597) } \\
\text { Open (1499) } \\
\text { Blue oak (34) } \\
\text { Live oak (49) } \\
\text { Digger pine (14) } \\
\text { Buck brush (1) }\end{array}$} & 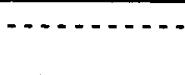 & $-\ldots . .-1$ & $\cdots+\cdots,-1$ & $\ldots$ & - & $\ldots \ldots$ \\
\hline & $4214 \pm 114$ & & & & & \\
\hline & $4295 \pm 119$ & $361 \pm 1029$ & $1550 \pm 861 * 1$ & $2069 \pm 1593^{*}$ & & \\
\hline & $3664 \pm 685$ & & $919 \pm 1324$ & $1438 \pm 1884$ & & \\
\hline & $2745 \pm 434$ & & & $519 \pm 1799$ & & \\
\hline & $2226 \pm 956$ & & & & & \\
\hline & 1604 & & & & & \\
\hline \multicolumn{7}{|c|}{ Open-rolling uplands } \\
\hline \multirow{6}{*}{$\begin{array}{l}\text { All types (1221) } \\
\text { Open (1130) } \\
\text { Blue oak (71) } \\
\text { Live oak (14) } \\
\text { Digger pine (5) } \\
\text { Buck brush (1) }\end{array}$} & $3144 \pm 108$ & & & & & \\
\hline & $3118 \pm 111$ & $-683 \pm 603^{*}$ & $1104 \pm 1325$ & $248 \pm 2209$ & & \\
\hline & $3802 \pm 510$ & & $1788 \pm 1441^{*}$ & $931 \pm 2280$ & & \\
\hline & $2014 \pm 1084$ & & & $-857 \pm 2567$ & & \\
\hline & $2871 \pm 2058$ & & & & & \\
\hline & 2844 & & & & & \\
\hline & \multicolumn{6}{|c|}{ Rocky-brushy uplands } \\
\hline All types (4533) & $2061 \pm 40$ & & & & & \\
\hline Open $(3600)$ & $2070 \pm 45$ & $-758 \pm 245^{*}$ & $351 \pm 209^{*}$ & $439 \pm 281^{*}$ & $165 \pm 544$ & $532 \pm 832$ \\
\hline Blue oak (270) & $2828 \pm 184$ & & $1109 \pm 309^{*}$ & $1197 \pm 362^{*}$ & $922 \pm 589^{*}$ & $1289 \pm 862^{*}$ \\
\hline Live oak (386) & $1719 \pm 116$ & & & $88 \pm 337$ & $-186 \pm 574$ & $181 \pm 852$ \\
\hline Digger pine (203) & $1631 \pm 145$ & & & & $-274 \pm 604$ & $93 \pm 873$ \\
\hline Buck brush (52) & $1905 \pm 327$ & & & & & $367 \pm 898$ \\
\hline Other (22) & $1538 \pm 317$ & & & & & \\
\hline
\end{tabular}

'Asterisk indicates that herbage production under the overstory in the column differs significant $(P<0.05)$ by Tukey's w-procedure from that under the overstory at the left. $295 \%$ confidence interval was not estimated.

During drought, however, live oaks and digger pines may produce opposite effects (Frost and McDougald 1989). The result of no difference in standing crops under buck brush and in the open agrees with that reported by Gaylord and Westfall (1971).

The results for unfertilized pastures generally agree with what we expect for herbage standing crops at the Experimental Range. We would expect swales to have higher peak standing crops where they receive full sunlight. They have relatively deep alluvial soils (Talbot et al. 1942) and receive runoff water as well as normal amounts of precipitation. Open-rolling and rocky-brushy uplands have relatively shallow, coarse textured soils. Their water holding capacities are low and water quickly percolates through the soil (Talbot et al. 1942). On those range sites, blue oak trees produce a microhabitat more favorable to herbage production than open areas. Soil under blue oaks has more humus, greater water holding capacity, and a better nutrient status. The tree canopies also moderate soil temperatures and slow drying (Holland 1980).

As to why standing crops under live oaks and digger pines may be less than under blue oaks or in the open, live oaks shade the soil all year and tend to grow in dense groups. They could effectively reduce light levels (Parker and Muller 1982) and photosynthesis by herbaceous plants. Coniferous leaf litter, which tends to be more fibrous and more acid, is more resistant to decomposition than dicotyledonous litter (Millar 1974). A heavy accumulation of litter under digger pines could lower emergence rates, or soil chemistry could inhibit germination of some species, or both. The shade provided by live oaks and possibly digger pines, however, may be more beneficial than harmful for herbage production during drought (Frost and McDougald 1989).

No significant overstory effects were found on the fertilized pastures (Fig. 1). While this situation may result partly from sample size, the effect of the fertilizer may have been to improve the soil nutrient status under the different overstory types relative to each other, and thereby even out differences in standing crops. That effect was evident among sites in the fertilized and unfertilized continuously grazed pastures (Caldwell et al. 1985). With fertilizatinn standino erenc averaged the came in cwolas. 1 kota oraster an open-rolling upland, and $36 \%$ greater on rocky-brushy upland than without it.

Compared with the situation in the unfertilized pastures, any actual fertilizer effects may reduce standing crops in open areas relative to blue oaks on swales but increase them on open-rolling and rocky-brushy uplands. For the fertilized and unfertilized pastures average standing crops in the open, expressed as percentages of those under blue oaks, were as follows:

\begin{tabular}{|c|c|c|}
\hline & Fertilized & percent \\
\hline $\begin{array}{l}\text { Swales } \\
\text { Upland }\end{array}$ & 86 & 117 \\
\hline $\begin{array}{l}\text { Open-rolling } \\
\text { Rocky-brushy }\end{array}$ & $\begin{array}{r}116 \\
84\end{array}$ & $\begin{array}{l}82 \\
73\end{array}$ \\
\hline
\end{tabular}

\section{Species Frequencies}

Grazing, soil properties, the kind of overstory, and the degree of micro-climate moderation all influence herbaceous species frequencies and abundances. In the shade of coast live oak (Quercus agrifolia), wild oats cover, frequency, and dry weight were less than in the open (Parker and Muller 1982). At the University of California's Hopland Field Station, percentages of composition (based on 50 points per plot) were higher for ripgut brome and annual fescue under blue oaks and higher for soft chess and broad-leaf filaree in the open (Bartolome 1986). Broad-leaf filaree was not found in the understory, while blue oak canopy did not affect slender wild oats or other broad-leaf plants. Herbage composition within overstory species differed less between annual grass/woodland ranges than between open areas and those with trees at each study location (Bartolome 1987).

Similar overstory influences on the herbaceous species were evident at the Experimental Range (Fig. 2). While obviously not equally frequent, all species or groups were found in the open on fertilized and unfertilized range. Under each overstory species, however, one or more understory species or groups appeared to have restricted distributions by being absent or infrequent. For examole. Mediterranean barlev and grasslikes seldom grew under 

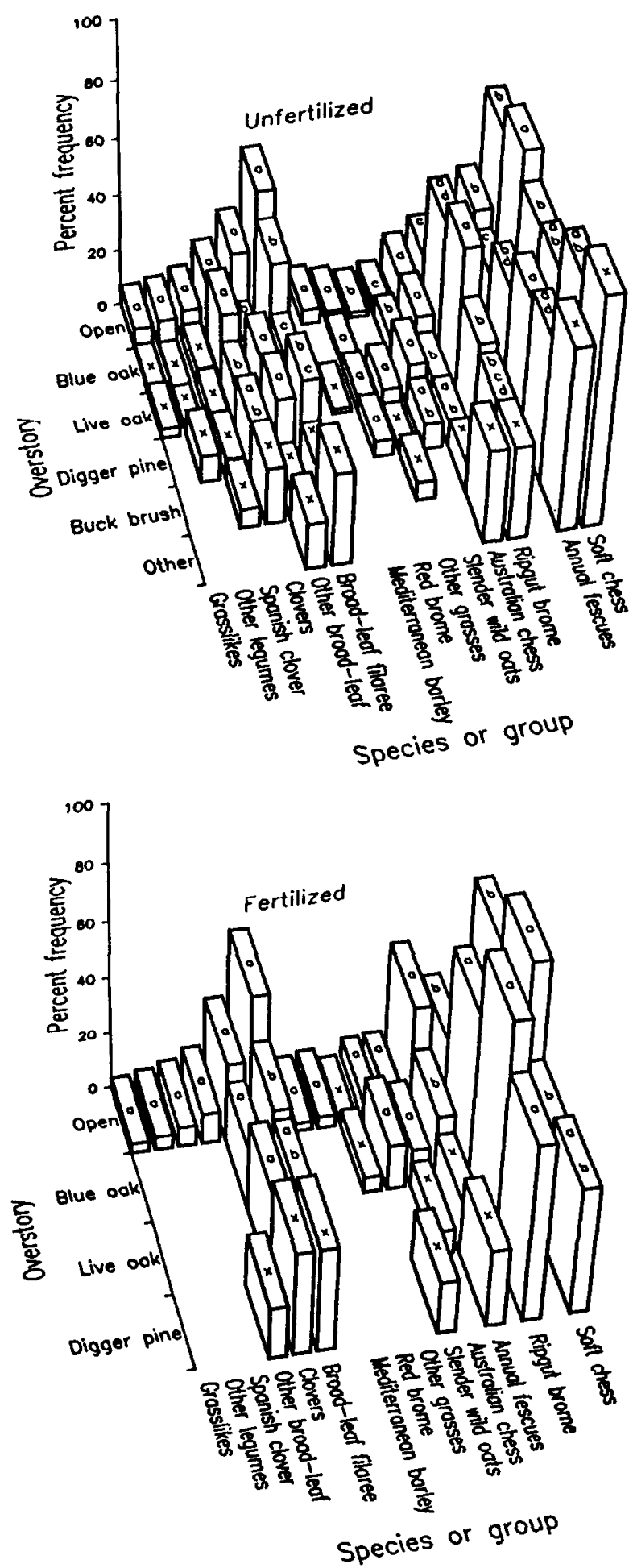

Fig. 2. Herbaceous species frequencies on unfertilized and fertilized range by overstory species at the San Joaquin Experimental Range, 1961-1968. Within a herbaceous species or group, frequencies with the same letter do not differ between overstory species. The $95 \%$ confidence interval (I) for $p_{1}-p_{2}$ covered zero. An $x$ means that either $p\left(n_{i j}\right)$ or $q\left(n_{i j}\right)$ was 5 or less and that the $C I$ was not computed; $n_{1 i}$ is the number of quadrats whete species (i) occurred under overstory (j).

the trees.

The data suggest that at the Experimental Range blue oaks, live oaks, and digger pines moderate the environment to favor species of later successional stages. Wild oats, soft chess, and ripgut brome belong to later successional stages on California's annual grass- lands (Sampson et al. 1951). Clovers, annual fescues, and filaree belong to mid-successional stages; and red brome and other broadleaved plants belong to early stages.

Compared with open areas, overstory species on unfertilized pastures at the Experimental Range had the following effects (positive $=$ more and negative $=$ less frequent than expected by chance) on understory plant frequencies (Fig. 2):

\begin{tabular}{|c|c|c|c|}
\hline \multirow[b]{2}{*}{ Understory plant } & \multirow[b]{2}{*}{ Blue oak } & \multicolumn{2}{|c|}{ Overstory species } \\
\hline & & Live oak & Digger pine \\
\hline Slender Wild oats & Positive & Positive & Positive \\
\hline Soft chess & Positive & & \\
\hline Ripgut brome & Positive & Positive & Positive \\
\hline Australian chess & & Negative & \\
\hline Other grass & & Positive & \\
\hline Clovers & & Negative & \\
\hline Spanish clover & & Negative & \\
\hline Annual fescues & Negative & & Positive \\
\hline Broad-leaf filaree & Negative & Negative & Negative \\
\hline Other broad-leaf & Negative & & \\
\hline
\end{tabular}

Buck brush enhanced the growth of annual fescues, but did not reduce that of soft chess and broad-leaf filaree and increase the growth of ripgut brome, as reported earlier by Gaylord and Westfall (1971).

Compared with blue oaks, other overstory species on unfertilized pastures at the Experimental Range had the following effects on understory plants (Fig. 2):

\begin{tabular}{|c|c|c|c|}
\hline \multirow[b]{2}{*}{ Understory plant } & \multirow[b]{2}{*}{ Live oak } & \multicolumn{2}{|c|}{ Overstory species } \\
\hline & & Digger oak & Buck brush \\
\hline Slender Wild oats & Positive & & \\
\hline Ripgut brome & & Negative & \\
\hline Australian chess & Negative & & \\
\hline Clovers & Negative & & \\
\hline Annual fescues & Positive & Positive & Positive \\
\hline Broad-leaf filaree & Negative & & \\
\hline Other broad-leaf & Positive & Positive & \\
\hline
\end{tabular}

Compared with live oaks, digger pines and buck brush at the Experimental Range had negative effects on ripgut brome. Digger pines had a positive effect on the annual fescues.

\section{Conclusions}

On or near the San Joaquin Experimental Range, woody plant harvest or control intended to increase herbage production should concentrate on species other than blue oak. Except in the swales, blue oaks can increase peak standing crops. At least on some range sites live oaks and digger pines reduce peak standing crops compared with open areas. Moreover, all overstory species reduce peak standing crops compared with blue oaks on the rocky-brushy uplands.

A diversity of overstory species may help to maintain adequate species diversity among understory species. Different herbaceous species appear to be favored by different overstory species. For example, the group "other grasses" was more frequent under live oaks than in the open. And on shallow soils, digger pines may help maintain species of later successional stages. Therefore, planning of woody plant harvests should carefully consider long-term maintenance of overstory species populations, and maintenance of the understory plant pool.

\section{Literature Cited}

Bartolome, J.W. 1986. Herbaceous productivity in oak woodland, p. 112116. In: Kie, J.G., and W.F. Laudenslayer, Jr. (eds.). Transactions of the western section of the Wildlife Society, Vol. 22;1986 Jan. 23-25; Sparks, Nev.

Bartolome, J.W. 1987. California annual grassland and oak savannah. Rangelands 9:122-125. 
Bentley, J.R., and M.W. Talbot. 1951. Efficient use of annual plants on cattle ranges in the California foothills. USDA, Washington, D.C. Circ. 870.

Bolsinger, C.L. 1987. Major findings of a statewide resource assessment in California, p. 291-297. In: T.R. Plumb and N.H. Pillsbury (tech. coords.). Proc. symp. on multiple-use management of California's hardwood resources; 1986 Nov. 12-14; San Luis Obispo, Calif. Gen. Tech. Rep. PSW-100. USDA, Forest Serv., Pacific Southwest Forest and Range Exp. Sta., Berkeley, Calif.

Caldwell, R.M., J.W. Menke, and D.A. Duncan. 1985. Effects of sulfur fertilization on productivity and botanical composition of California annual grassland. J. Range Manage. 38:108-113.

Dixon, W.J., and F.J. Massey, Jr. 1957. Introduction to statistical analysis. 2nd ed. McGraw-Hill, Inc., New York.

Duncan, D.A. 1967. Blue oak canopy effect on herbage yield of central California foothill rangeland, p. 61-62. In: Abstr., 20th Annu. Meeting, Amer. Soc. Range Manage., Seattle, Wash.

Duncan, D.A., and W.J. Clawson. 1980. Livestock utilization of California's oak woodlands, p. 306-313. In: T.R. Plumb (tech. coord.). Proc. symp. on the ecology, management, and utilization of California oaks; 1979 June 26-28; Claremont, Calif. Gen. Tech. Rep. PSW-44. USDA, Forest Serv., Pacific Southwest Forest and Range Exp. Sta., Berkeley, Calif.

Duncan, D.A., and J.N. Reppert. 1960. A record drought in the foothills. Misc. Paper 46. USDA, Forest Serv., Pacific Southwest Forest and Range Exp. Sta., Berkeley, Calif.

Frost, W.E., and N.K. McDougald. 1989. Tree canopy effects on herbaceous production of annual rangeland during drought. J. Range Manage. 42:281-283.

Gaylord, V.J. 1972. A method for the correlation of range sites with land association classes in the Sierra foothills. M.S. Thesis, California State Univ., Fresno.

Gaylord, V.J., and S.E. Westfall. 1971. Wedgeleaf ceanothus canopy does not affect total herbage yield. Res. Note PSW-253. USDA, Forest Serv., Pacific Southwest Forest and Range Exp. Sta., Berkeley, Calif. Holland, V.L. 1976. In defense of blue oaks. Fremontia 4:3-8.
Holland, V.L. 1980. Effect of blue oak on rangeland forage production in central California, p. 314-318. In: T.R. Plumb (tech. coord.). Proc. symp. on the ecology, management, and utilization of California oaks; 1979 June 26-28; Claremont, Calif. Gen. Tech. Rep. PSW-44. USDA, Forest Serv., Pacific Southwest Forest and Range Exp. Sta., Berkeley, Calif.

Kay, B.L. 1987. Long-term effects of blue oak removal on forage production, forage quality, soil, and oak regeneration, p. 351-357. In: T.R. Plumb and N.H. Pillsbury (tech. coords.). Proc. symp. on multiple-use management of California's hardwood resources; 1986 Nov. 12-14; San Luis Obispo, Calif. Gen. Tech. Rep. PSW-100. USDA, Forest Serv., Pacific Southwest Forest and Range Exp. Sta., Berkeley, Calif.

Kay, B.L., and O.A. Leonard. 1980. Effect of blue oak removal on herbaceous forage production in the North Sierra Foothills. p. 323-328. In: T.R. Plumb (tech. coord.). Proc. symp. on the ecology, management, and utilization of California oaks; 1979 June 26-28; Claremont, Calif. Gen. Tech. Rep. PSW-44. USDA, Forest Serv., Pacific Southwest Forest and Range Exp. Sta., Berkeley, Calif.

Larson, J.H., J. Stebbins, and W.L. Porter, Jr. 1985. A revised checklist of the plants of the San Joaquin Experimental Range. CATI/850303. California Agr. Technol. Inst., Fresno, Calif.

Millar, C.S. 1974. Decomposition of coniferous leaf litter, p. 105-128. In: C.H. Dickinson and G.J.F. Pugh (eds.), Biology of plant litter decomposition, Vol. 1. Academic Press, New York.

Parker, V.T., and C.H. Muller. 1982. Vegetational and environmental changes beneath isolated live oak trees (Quercus agrifolia) in a California annual grassland. Amer. Midl. Natur. 107:69-81.

Ratliff, R.D. 1986. Cattle responses to continuous and seasonal grazing of California annual grassland. J. Range Manage. 39:482-485.

Sampson, A.W., A. Chase, and D.W. Hedrick. 1951. California grasslands and range forage grasses. Univ. Calif., Berkeley. Bull. 724.

Steel, R.G.D., and J.H. Torrie. 1960. Principles and procedures of statistics. McGraw-Hill, Inc., New York.

Talbot, M.W., J.W. Nelson, and R.E. Storie. 1942. The experimental area. p. 7-12. In: C.B. Hutchison, and E.I. Kotok (eds.), The San Joaquin Experimental Range. Univ. Calif., Berkeley. Bull. 663.

Westfall, S.E., and D.A. Duncan. 1961. The San Joaquin cage. J. Range Manage. 14:355.

Should we Dial a-Satellite to find your new address? Just sending us your new address along with an old label will probably get your journai to you faster. (No criticism of satellites intended!) Send the information to Society for Range Management, 1839 York Street, Denver, Colorado 80206. 